\title{
SOCIAL RESPONSIBILITY PROJECTS IN A COMPARATIVE PERSPECTIVE IN THE NEW CONTEXT OF ECONOMIC DEVELOPMENT
}

\author{
Maria LOGHIN ${ }^{a *}$, Răzvan Cătălin DOBREA ${ }^{b}$, Cristian Alexandru ŞTEF $\breve{A N E S C U}{ }^{c}$ \\ ${ }^{a, b, c}$ Bucharest University of Economic Studies, Romania
}

\begin{abstract}
Corporate Social Responsibility (CSR) was one of the most debated concepts during time, with a variety of definitions. Starting with 2030 Agenda, launched by UN Summit in New York in 2015, CSR perception begin to have a common shape. This paper is a literature review and has the intention to describe the current approach in implementing CSR in Norway, Finland and Denmark. The article also emphasizes the weaknesses of each model analyzed based on the percentage of fulfillment of Sustainable Development Goals (SDGs) from 2030 Agenda. The article also gives a solution for this unprecedented triple crisis: economic, health and environmental.
\end{abstract}

KEYWORDS: 2030 Agenda, CSR, SDGs

DOI: 10.24818/IMC/2021/05.05

\section{INTRODUCTION}

CSR is a concept which has been defined and redefined during time based on the culture, history and the level of development of each country. Today, CSR still does not have a common definition, but we can say it incorporates widely three pillars: economic, environmental and social. If economic and environmental pillars are suggestive enough, the social pillar was not so well expounded from early beginning (Panapanaan et al., 2003). Nowadays, the social pillar is considered of high interest and it covers the ethical/social behavior of board of directors with respect to employees, customers, suppliers and community (Panapanaan et al., 2003). Even so, there still different ways of implementing CSR in the organizations, but the worst is that many organizations just ignore the concept or claim that they are including CSR in their process, but in fact this is not true. Lately, with Covid-19 pandemic things seems to become unbelievable more complicated (Sachs, 2021). More exactly the world seems to face a triple crisis: economic, health and environmental (Koundouri, 2021). Even so, accordingly Koundouri (2021), the answer to the question of how countries can recover from this unprecedented triple crisis is given by SDGs and Paris Agreement on climate change.

This research contributes to the literature by offering a view of the previous studies related to the history and framework of CSR used in Norway, Finland and Denmark. Also, this paper adds an important contribution to the current literature through the fact it analysis the current status of 2030 Agenda and SDGs implementation in Norway, Finland and Denmark. More exactly the study will emphasize for each country analyzed the cluster of SDGs that needs improvements.

The rest of the paper is organized as follows. Section 2 elaborates the methodology used for creating the article. Section 3 emphasizes the results of literature review. Finally, we conclude the main findings of the study.

\footnotetext{
*Corresponding author. E-mail address: marialoghin1992@gmail.com
} 


\section{RESEARCH METHODOLOGY}

This article has the intention to describe the current approach in implementing CSR used in Norway, Finland and Denmark. These countries were chosen based on their high index in implementing SDGs. This assessment is important for further evaluation and correction of weaknesses from CSR implementation in Romania. This paper is a literature review. The literature review is realized for achieving a general understanding of the CSR models used in Norway, Finland and Denmark, but also to emphasize the weaknesses of each model analyzed based on the percentage of fulfillment of SDGs from 2030 Agenda. The database used in this research is represented by Web of Science but is not limited to it. Concluding, this review is important for understanding how countries with a low level of SDGs fulfillment can improve their actions related to accomplishing the goals from 2030 Agenda, by taken as example the Nordic countries analyzed.

\section{RESULTS}

\subsection{Norway}

According to (Ihlen \& von Weltzien Hoivik, 2019) Norway needed many years of practice before getting a stable framework for achieving current CSR agenda goals. In $17^{\text {th }}$ century the nobility had a tiny percentage, fact which had led to a symmetric society, creating the basis for a later CSR practice (Ihlen \& von Weltzien Hoivik, 2019). Furthermore, mining activities resulted in the creation of first larger companies in Norway, which in turn supported their employees with high salaries (Ihlen \& von Weltzien Hoivik, 2019). Even so, first measures related to CSR activities were the result of government requirements and not the effort of business directors (Ihlen \& von Weltzien Hoivik, 2019).

Starting with $19^{\text {th }}$ century, in Norway, Hauge standards, which included "fair salaries, food and clothing" for all employees have received political acceptance (Ihlen \& von Weltzien Hoivik, 2019). After democratic revolution and the irritation burst from social damage created by companies' actions, Thrane standard, which included social welfare measure, was introduced in business environment (Ihlen \& von Weltzien Hoivik, 2019).

At the beginning of the $20^{\text {th }}$ century, some directors decided to offer more to their own employees, and we can take as example the case of Freia company, where "building houses for workers, profit sharing schemes, health care services, a 48-hour work week and the provision of 14 days paid vacation" were the new benefits given by employer (Ihlen \& von Weltzien Hoivik, 2019).

In 1930s new government regulations were adopted regarding social welfare, as business started to exclude the society needs and look only for its own profit (Sejersted, 2003 cited in Ihlen \& Von Weltzien 2019).

In 1935, labor and farmer party asked for economic modernization legalized by government: limiting the workday at eight hours, "nine days of payed vacation" and "introducing prohibition of the unwarranted firing for workers" (Ihlen \& von Weltzien Hoivik, 2019).

Furthermore, in 1972 all organizations with more than 200 employees were asked by government to institute the representatives of employees (Ihlen \& von Weltzien Hoivik, 2019).

Starting from 1998 Norway government required all companies to be transparent regarding their environmental actions, health and safety measurements (Grenness, 2003).

If in 1999 the term of CSR was firstly used in a newspaper, in 2000, in Norway and Europe, CSR was including "human rights", "laws for child labor", "employees" rights" and the "fight anticorruption" (Ihlen \& von Weltzien Hoivik, 2019). Same human rights, Norwegian business should respect also abroad as the government made strict clarifications in this direction (Ihlen \& von Weltzien Hoivik, 2019).

Until 1980 the political culture was characterized by public - private cooperation including nongovernmental organizations in the environmental pillar (Ihlen \& von Weltzien Hoivik, 2019). 
Today, CSR in Norway model is including the "society welfare", "social security" and "full employment" through government involvement in the negotiations of employee's rights with business sector (Ihlen \& von Weltzien Hoivik, 2019).

While many European countries have philanthropy part of CSR actions, this can't be said by Norway, where the egalitarian is the specific feature of the society. During time, this idea was sustained by business environment which sow philanthropy as non-sense actions for the society prosperity (Ihlen \& von Weltzien Hoivik, 2019).

According Norway's follow-up of Agenda 2030 and the Sustainable Development Goals, there are some needed actions in what concern: pollution generated from production (goal 2), low number of teachers with cultural and language skills for kids with trauma after war circumstance (goal 4), the negative impact of climate change (goal 6), negative environmental effects limited through Norway's transport systems for converting Norway into a low-emission society (goal 9), accommodating population growth with sustainable urban development (goal 11), sustainable use of natural resources (goal 12), obtaining an ambitious climate policy (goal 13), intensify global measures to stop and eliminate marine litter and micro-plastics (goal 14), promoting ambitious environmental commitments, as a leader, in international context (goal 15), supporting the UN's efforts in promoting peaceful and inclusive societies (goal 16) (Ministries of Norway, 2016).

\subsection{Denmark}

In Denmark, CSR practices are strongly encouraged by government as a strategy to reduce unemployment, social exclusion or the number of people who benefit of allowance (Metaxas \& Tsavdaridou, 2010). One of the decisions taken by Danish government was the foundation of "social coordination committee" in 1998 (Metaxas \& Tsavdaridou, 2010). The purpose of the new committee was the setup of new social legislation and the addendum in the strategy of labor market (Metaxas \& Tsavdaridou, 2010). In 1999, Danish government took a step further through "social chapter". The initiative had as main purpose the stimulation of local authorities to employ people from social excluded categories through cooperation with local authorities (Metaxas \& Tsavdaridou, 2010). That social excluded categories cover elderly people, persons unemployed for a long period of time or people with disabilities. Another decision taken by Danish government was the operation "Our common Concern" (Metaxas \& Tsavdaridou, 2010). The outcomes of this initiative were: a better disclosure of CSR topics, conferences attended, partnerships between organizations, foundation of units for CSR, a major reduction of unemployment between 1994 and 2000 , the growth of the employment period and the reduction of people number which were supported through allowance (Metaxas \& Tsavdaridou, 2010).

The mediator between Danish government, organizations, social performers and local authorities is the Copenhagen Center, which in 2007 was unified with Center for Social Responsibility. This unified center has as main occupations the surveys invention, reports production and seminars presentation (Metaxas \& Tsavdaridou, 2010).

For offering a better understanding of CSR actions in business, to acquire constructive results, to obtain a positive image and expected economic advantage and encourage directors of SME to adopt a framework of business based on CSR principles, Danish Commerce and Company Agency created an empiric guide for CSR, namely "People and Profit" (Metaxas \& Tsavdaridou, 2010).

Regarding the level of transparency, Denmark is on top of the ranking comparing to other countries analyzed (Metaxas \& Tsavdaridou, 2010).

In what concern environmental activities, Denmark is trying to prevent pollution, to minimize the waste and to reduce the energy, water and materials consumption (Kjær, n.d).

We can conclude, Denmark is using the three pillars model as framework for CSR strategies, excluding philanthropic activities.

According to Ministry of Foreign Affairs of Denmark (2017, January), Denmark is viewing goal no. 16 and goal no. 17 as main goals, because they are incorporating the objective of all the rest. 
Regarding international context, Denmark will engage in countries and regions - based on each specific context - that can be split into three categories: 1. Poor, fragile countries and regions characterized by fragility; 2. Poor, stable countries; 3. Transition and growth economies. Furthermore, in the international context, five SDGs will be emphasized: goal no. 5, goal no. 7, goal no. 13, goal no. 16 and goal no. 17 (Ministry of Foreign Affairs of Denmark, 2017).

Regarding national context, in 2017 Denmark established its Action Plan as a guideline for the implementation and follow up of the 2030 Agenda, fact mentioned by European Environment Agency (2020). Danish Report for the Voluntary National Review emphasize that the Action Plan is focused on: Prosperity, People, Planet, Peace and Partnerships. Each of these points are integrating some targets - 37 in total - which merge several SDGs (Danish Ministry of Finance, 2017). In what concern Prosperity, the government is trying to offer more economic freedom for families and job certainly (Danish Ministry of Finance, 2017). Prosperity is including all SDG, except SDG no. 14 (Danish Ministry of Finance, 2017). Second point, People, is about human's freedom, considering access to education and healthcare without the impact of economic and social influence (Danish Ministry of Finance, 2017). People objective is including SDG no. 3, SDG no. 4, SDG no. 5, SDG no. 8, SDG no. 9, SDG no. 10 and SDG no. 16 (Danish Ministry of Finance, 2017). Regarding Planet, Denmark is globally involved in speeding green transition in all domains, fact that involves all the SDGs, except SDG no. 1, SDG no.4, SDG no.5, SDG no. 10, SDG no. 16 and SDG no. 17 (Danish Ministry of Finance, 2017). Finally, Peace objective is about government efforts to eliminate crime and terror and incorporates all the goals, except Goal no. 16 (Danish Ministry of Finance, 2017).

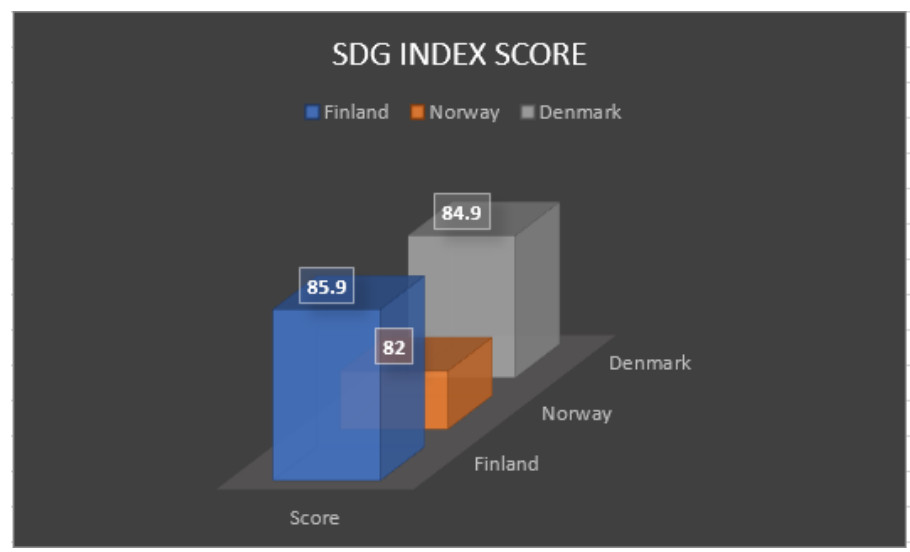

Figure 1. SDG Index Score 2021

Source: adapted from Sachs et al. (2021)

\subsection{Finland}

Globalization process of business environment led to the spread of CSR in Finish organizations and the involvement of trade unions in defining CSR (Lämsä \& Viljanen, 2014). Basically, trade unions reinforced the regulations by law between employees and employers and regulates the collective negotiations between employees and employers (Lämsä \& Viljanen, 2014). In international context, trade unions are cooperating with foreign unions, non-governmental organizations (NGO) and multinational organizations (Lämsä \& Viljanen, 2014). According to Kujala (2004), the traditional principles of Finns, honesty, trustworthiness, responsibility and reliability are shaping the basis for today CSR. In addition to this principles, national legislation, EU regulation and codes of conduct established by organizations represents the framework of CSR in Finland (Lämsä \& Viljanen, 2014). Even in early industrial forms of organizations, the board of directors were offering to employees, houses, health care services, schools and canteen, since the government legislation on CSR, philanthropy activities are seen important only for multinational organizations, when they operate in less developed countries (Lämsä \& Viljanen, 2014). Today, social and welfare services 
are established through legislation and indigenous are viewing them as universal rights (Lämsä \& Viljanen, 2014).

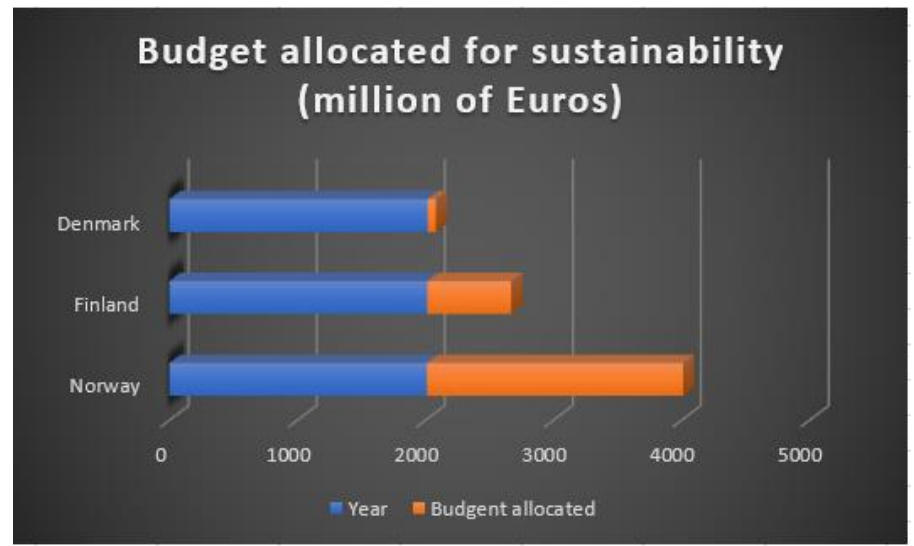

Figure 2. Budget allocated for sustainability

Source: adapted from Market size of sustainable and responsible investments (SRI) in Finland in 2013 and 2015, by strategy, (2018)

Sustainability themed investments SRIs in Norway in 2011 and 2013, (2016) Sustainability themed responsible investments (SRI) in Europe in 2017, by country, (2018).

According to (Panapanaan et al., 2003) almost 83 percent of Finish interviewers, from 12 different companies, agreed that CSR is integrated into the process of an organization.

(Panapanaan et al., 2003) emphasize that Finland used the CSR three pillars model for 40 years ago, because companies were acting since then environmentally friendly and socially responsible.

Most used domains in implementing CSR in Finland are: "customer satisfaction", "pursuit of quality/excellence", "continuous improvement", "respect for employees (and others)", "profitability", "trust", "openness", "respect for the environment or environmental protection", "honesty", "cooperation", "independence", "creativity/innovation", "service to society", "enterprising spirit", "importance of compliance", "initiative", "flexibility" (Panapanaan et al., 2003).

After an accounting act amendment accepted on 29 December 2016, all large undertakings, listed companies, credit institutions and insurance companies which have an average of at least 500 employees are called for publishing their reports about CSR (Ministry of Economic Affairs and Employment of Finland, n.d).

According Prime Minister's Office of Finland (2020), starting from 2017 Finland is reporting on its progress related to achieving 2030 Agenda for Sustainable Development, with a recurrency of one at four years. Finland is one of the top countries in what concern sustainability, as Sustainable Development Solutions Network reported, being third in 2019 report (Sachs et al., 2019) and first on 2021 report (Sachs et al., 2021). On the other hand, the 2019 report emphasize the need for action in what concern SDG2, SDG12, SDG14 and SDG17 (Prime Minister's Office of Finland, 2020). In the international context, Finland must address vulnerable groups, taking as example the experience of other countries which are leading with their experiences (Prime Minister's Office of Finland, 2020).

\section{CONCLUSIONS}

After this journey we can conclude Nordic countries share a couple of common features. One of them is the involvement of government in CSR legislation, fact which had led indigenous people viewing social and environment actions as part of organizations universal responsibilities. Second common feature is transparency, with the observation that Denmark is on top of ranking regarding 
report publishing. Furthermore, and I think one of the most important features of the countries analyzed is the use of three pillars model by all of them - economic, environmental and social - in CSR implementation, with the observation that in Finland CSR is integrated in the organizations process level. On the other hand, excluding philanthropy from all the models analyzed is another common feature adopted by Nordic countries as a result of the symmetric societies. One exception is the international context, where each country will be involved based on the level of scarcity of the country where they operate.

Apart from the common features in the models analyzed we can also see some differences. One of them is the way Denmark is trying to achieve 2030 Agenda for Sustainable Development. If Finland and Norway are reporting the need of improvement based on each goal from 2030 Agenda, Denmark has an Action Plan base on Prosperity, People, Planet, Peace and Partnerships. More exactly we can see differences in the SDGs that need improvement in each country analyzed: if Finland needs improvements in SDG no. 2, SDG no. 12, SDG no. 14 and SDG17, Norway needs some improvements related to SDG no. 2, SDG no. 4, SDG no. 6, SDG no. 9, SDG no. 12, SDG no. 11, SDG no. 13, SDG no. 14, SDG no. 15 and SDG no. 16, while Denmark needs improvements in all SDGs except SDG no. 14 when we talk about Prosperity, SDG no. 3, SDG no. 4, SDG no. 5, SDG no. 8, SDG no. 9, SDG no. 10 and SDG no. 16 in case of People objective, SDG no. 1, SDG no.4, SDG no.5, SDG no. 10, SDG no. 16 and SDG no. 17 if we think about Planet and all SDGs except SDG no. 16 in case of Peace objective. There are also differences in what concern SDG Index score. If we have a look to Figure 1, Finland has the highest SDG index (85.9), followed by Denmark (84.9) and Norway (82). Also, we can see differences in the budget allocated by each country analyzed: Finland allocated 656 million of euros in 2015 for CSR (Market size of sustainable and responsible investments (SRI) in Finland in 2013 and 2015, by Strategy, 2018), Norway 2 billion of euros in 2013 (Sustainability themed investments SRIs in Norway in 2011 and 2013, 2016) and Denmark 65 million of euros in 2017 (Sustainability themed responsible investments (SRI) in Europe in 2017, by country, 2018).

As a main conclusion, in Nordic countries the societal and environmental pillars of CSR were forced by state and church, but the seeds were the traditional principles of indigenous people: honesty, trustworthiness, responsibility and reliability. Basically, we can say CSR was not a totally new concept that needed to be introduced in Finland, Norway or Denmark, but just completed with new regulation during time and named accordingly. Through the results of this paper, one of our main research objectives - the deep study of corporate social responsibility projects at European level - has been reached.

In Romania, through adopting good international practices, like jobs creation, the poverty can be severely reduced (Firoiu et al., 2019). Also, jobs creation can reduce the number of people which are supported through allowance. Furthermore, medical services should be equal for all people in Romania, no matter their social position and level of salary.

Regarding pandemic context, current authorities have the obligation to build next generations feature in a way that will not affect their prosperity, peace, security and human rights. Here we can take as example Norway, where people started to move to everyday normal life, without blocking anymore the economy or education. More exactly all restriction were removed except the case you have respiratory symptoms, and you need to test yourself, even if you are vaccinated or not and get isolated if the result is positive (The Norway Office of the Prime Minister, 2021). Furthermore, the restarting of the economies should be done in a sustainable way regarding environmental (Koundouri, 2021) and social pillars. Even so, looking at the global situation generated by health crisis, at the moment, the recovery in a sustainable way seems to be inaccessible for poor countries, if we take into account their financial situation (Koundouri, 2021). As a response to this situation, the International Monetary Fund (IMF) and World Bank will support with new $\$ 650$ billion the governments from low and middle-income countries in the fight with pandemic consequences (Koundouri, 2021). Starting from September 2021, the results of this new aid together with the 
existing Recovery and Resilience Facility, the world's recovery in a green and digital mood will be checked out in the next three years.

\section{ACKNOWLEDGMENT}

We would like to thank to the anonymous reviewers and for the technical support given by the editors.

This paper was co-financed by The Bucharest University of Economic Studies during the PhD program.

\section{REFERENCES}

Danish Ministry of Finance. (2017, June). Report for the Voluntary National Review. Retrieved July 17, 2021, from https://sustainabledevelopment.un.org/content/documents/16013Denmark.pdf

European Environment Agency. (2020, December 2). Denmark country profile - SDGs and the environment. Retrieved July 29, 2021, from https://www.eea.europa.eu/themes/sustainabilitytransitions/sustainable-development-goals-and-the/country-profiles/denmark-country-profilesdgs-and

Firoiu, D., Ionescu, G. H., Băndoi, A., Florea, N. M. \& Jianu, E. (2019). Achieving sustainable development goals (SDG): Implementation of the 2030 Agenda in Romania. Sustainability, 11(7), 2156.

Grenness, T. (2003). Scandinavian managers on Scandinavian management. International Journal of Value-Based Management, 16(1), 9-21.

Ihlen, Ø. \& von Weltzien Hoivik, H. (2015). Ye olde CSR: The historic roots of corporate social responsibility in Norway. Journal of Business Ethics, 127(1), 109-120.

Kjær, V. (n.d). The Danish policy for CSR: Partnerships and international business strategy. Retrieved July 7, 2021, from https://docplayer.net/21513658-The-danish-policy-for-csrpartnerships-and-international-business-strategy.html

Koundouri, P. (2021, June 17). The SDGs are the only road to recovery. SDG Action. Retrieved September 25, 2021, from https://sdg-action.org/the-sdgs-are-the-only-road-to-recovery/

Kujala, J. (2004). Managers' moral perceptions: change in Finland during the 1990s. Business Ethics: A European Review, 13(2-3), 143-165.

Lämsä, A. M. \& Viljanen, S. (2015). Finland: positive union engagement with CSR. In Corporate Social Responsibility and Trade Unions (pp. 57-74). Routledge.

Market size of sustainable and responsible investments (SRI) in Finland in 2013 and 2015, by strategy. (2018, November). In Statista. Retrieved May 29, 2021, from https://www.statista.com/statistics/426088/socially-responsible-investments-sri-finland-bystrategies/

Metaxas, T. \& Tsavdaridou, M. (2010). Corporate social responsibility in europe: Denmark, Hungary and Greece. Journal of Contemporary European Studies, 18(1), 25-46.

Ministries of Norway. (2016, July). Norway's follow-up of Agenda 2030 and the Sustainable Development Goals. Retrieved August 9, 2021, from https://www.uib.no/sites/w3.uib.no/files/attachments/norways_follow-up_of_agenda_2030 _and_the_susatinable_development_goals.pdf

Ministry of Economic Affairs and Employment of Finland. (n.d.). CSR reporting obligation: Which companies does it apply to and what is required? Retrieved August 25, 2021, from https://tem.fi/en/csr-reporting 
Ministry of Foreign Affairs of Denmark. (2017, January). The World 2030 Denmark's strategy for development cooperation and humanitarian action. Retrieved June 15, 2021, from https://amg.um.dk/en/policies-and-strategies/stategy-for-danish-development-cooperation

Panapanaan, V. M., Linnanen, L., Karvonen, M. M. \& Phan, V. T. (2003). Roadmapping corporate social responsibility in Finnish companies. Journal of business ethics, 44(2), 133-148.

Prime Minister's Office of Finland. (2020). Voluntary National Review 2020 - Finland report on the implementation of the 2030 Agenda for Sustainable Development. Retrieved May 16, 2021, from https://sustainabledevelopment.un.org/content/documents/26261VNR_Report_Finland 2020.pdf

Sachs, J. (2021, July 20). A global roadmap for recovery. SDG Action. Retrieved September 25, 2021, from https://sdg-action.org/a-global-roadmap-for-recovery/

Sachs, J., Kroll, C., Lafortune, G., Fuller, G. \& Woelm, F. (2021). Sustainable Development Report 2021. Cambridge: Cambridge University Press.

Sachs, J., Schmidt-Traub, G., Kroll, C., Lafortune, G. \& Fuller, G. (2019). Sustainable Development Report 2019. New York: Bertelsmann Stiftung and Sustainable Development Solutions Network (SDSN). Retrieved September 24, 2021, from https://s3.amazonaws.com/sustainabledevelopment.report/2019/2019_sustainable_development report.pdf

Sustainability themed investments SRIs in Norway in 2011 and 2013. (2016, October 9). In Statista. Retrieved June 8, 2021, from https://www.statista.com/statistics/425719/socially-responsibleinvestments-norway-sustainability-themed/\#statisticContainer

Sustainability themed responsible investments (SRI) in Europe in 2017, by country. (2018, November). In Statista. Retrieved June 8, 2021, from https://www.statista.com/statistics/ 422438/socially-responsible-investments-europe-countries/

The Norway Office of the Prime Minister. (2021, September 25). Norway moves to normal everyday life with increased emergency preparedness. Retrieved October 04, 2021, from https://www.regjeringen.no/en/aktuelt/norway-moves-to-normal-everyday-life-with-increasedemergency-preparedness/id2872539/ 